\title{
The Performance of Two Anchor Domestic Malaysian Banks before and after Acquisition
}

\author{
Jakpar, S. ${ }^{1}$, Tinggi, M. ${ }^{1}$, Chong, W. T. ${ }^{1}$, Johari, A. ${ }^{2}$, Myint, K. T. ${ }^{2}$ \\ ${ }^{1}$ Faculty of Economics and Business, University Malaysia Sarawak (UNIMAS), Malaysia \\ ${ }^{2}$ Faculty of Business, Curtin University Sarawak Malaysia, Malaysia \\ Correspondence: Shaharudin Jakpar, Faculty of Economics and Business, University Malaysia Sarawak, 94300, \\ Kota Samarahan, Sarawak, Malaysia.
}

Received: August 2, 2017

doi:10.5539/ibr.v10n10p156
Accepted: September 11, $2017 \quad$ Online Published: September 25, 2017

URL: https://doi.org/10.5539/ibr.v10n10p156

\begin{abstract}
This article is undertaken to assess the performance of domestic Malaysian banks before and after acquisition. This paper focuses on two pairs of anchor banks which merged and acquired other minor banks in Malaysia from year 2001 until 2013. The research period is 2 years before and 2 years after the acquisitions. The method being used in this research is financial ratios and event study. Nine selected financial ratios were used in this research to find the difference between pre and post acquisitions. Whereas event study is used to find the abnormal return, average abnormal return, cumulative abnormal return, and t-test hypothesis. The e vent window in this research is a total of 21 days before and after the acquisitions including the actual day of the event announcement. The results for this research indicate that there was improvement for Hong Leong Bank and EON Bank. RHB Bank on the other hand was outperforming by Bank Utama. There were limitation when carrying out this research such as difficulties to retrieve the needed annual report and historical price to conduct the investigation. The time lag on certain banks performance may need more time to see a better result while others may perform well in short period.
\end{abstract}

Keywords: domestic banks performance, acquisition, financial ratios, annual report, financial crisis

\section{Introduction}

Malaysia banking sector underwent a major transformation in year 2000 due to the Asian Financial Crisis in year 1997. Malaysia Central Bank which is also known as Bank Negara Malaysia (BNM) initially planned for the 58 financial institutions (21 commercial banks, 25 finance companies, and 12 merchant banks) to merge into 10 anchor banks. According to Talha and Sallehhuddin (2005), there are two purposes of undergoing mergers, first is to ensure domestic banks are able to handle financial sector liberalization by the year 2003 and also to increase international competitive advantage. Second purpose of undergoing mergers is to create a stronghold of domestic banks to survive when financial crisis occur. Establishment of the 10 anchor banks increases the depositors' confidence and also established stronger and flexible banks (Talha \& Sallehhuddin, 2005).

The form of 10 anchor banks was resulted from the pressure of the Central Bank as stated in Shanmugam and Nair (2003). According to Shanmugam and Nair (2003), initially Bank Negara Malaysia (BNM) planned to have only six anchor banks in Malaysia and it was announced on 19 July 1999, however, due to objection from various quarters, the government increased the number of 6 anchor banks to 10 anchor banks. The program of having 10 anchor banks is to reduce the numbers of financial institutions in Malaysia from 54 to 10 financial institutions (Shanmugam \& Nair, 2003).

Merger is combining two or more companies then the new company can either use a new name or either the name of the buyer or the seller. Whereas, acquisition is where a company becomes history after the strong company acquired the weaker company. According to Ong and $\mathrm{Ng}$ (2013), merger and acquisition in Malaysia started in 1970s. During the financial crisis, the Malaysia government found that there was weakness in Malaysia banking system. According to Shanmugam and Nair (2003), during the financial crisis, smaller banks were not able to perform well. Therefore, the merging program of domestic banks aid the banks to be able to compete in global market and able to meet the demand of the changing of domestic economic structure. Other than that, merging and acquisition also helps the banking system to be more efficient (Shanmugam \& Nair, 2003). 
According to Sufian and Habibullah (2009), BNM supports mergers between domestic banks. One of the examples is during year 1994 where two-tier banking system was first introduced. The 2-tier system promotes mergers among domestic banks and also it allows the higher capitalized banks with tier-1 status to provide various ranges of financial products and services. However, the results were not that satisfying as there were only few mergers taking place at that moment in order to obtain tier-1 banking group benefits, whereas the smaller banks increases their capital to move from 2-tier to 1-tier banking group status (Sufian \& Habibullah, 2009).

According to Said, Nor, Low, and Rahman (2008), the process of getting Malaysia domestic banks to merged together were not going smoothly as the shareholders were protective over their own interests. This issue leads the smaller commercial banks and financial institutions into great distress as the program of mergers was first introduced to tackle the non-performing loans problem faced by smaller commercial banks and financial institutions during the financial crisis. In order to maintain a stable financial system, BNM came up with an emergency plan that is to decrease the number of commercial banks to 34 in year 1997. However, between year 1997 and 1998, Malaysia banking system faced with another disaster. At that moment, BNM decided to form 10 anchor banking group and the main 10 anchor banks are Malayan Banking Berhad (Maybank), Bumiputra-Commerce Bank Berhad, RHB Bank Berhad, Public Bank Berhad, Arab-Malaysian Bank Berhad, Hong Leong Bank Berhad, Perwira Affin Bank Berhad, Multi-purpose Bank Berhad, EON Bank Berhad, and Southern Bank Berhad (Said et al., 2008).

Merger and acquisition in Malaysia banking sector steadily increased over the year 2000 (Ong and Ng, 2013). Though there are 10 anchor banks in Malaysia, slowly in year 2006, 10 anchor banks became nine anchor banks as Southern Bank Berhad was acquired by CIMB Berhad in year 2006. In order for more merger and acquisition activities, the government grants the permission to have stamp duty exemption and real estate gain tax. According to Ong and $\mathrm{Ng}$ (2013), though Malaysia go vernment supports the activity of mergers and acquisitions between domestic banks, there is still no solid proof whether are they on the right track. Terjesen (2009) as cited in Ong and $\mathrm{Ng}$ (2013) found that most findings from previous researchers on mergers and acquisitions is the ability to decrease operating expenses, increase in market share and obtaining more competitive advantages.

From nine anchor banks, it turns out that EON Bank Berhad was acquired by Hong Leong Bank Berhad in October 2011 which makes it only 8 anchor banks left in year 2011 (Ong \& Ng, 2013). Two tables are shown as follow concerning the mergers and acquisitions (M\&A) activities going on throughout the year Malaysia started the activity. Table 1 represents the number of bank in Malaysia being merged and acquired over the years since 1980s until year 2011.

Table 1. Year and number of banks in Malaysia

\begin{tabular}{lcc}
\hline & Year & Number of banks \\
\hline Before Economic Recession in mid-1980 & 1980 & 80 banks \\
\hline After Economic Recession in mid-1980 & 1990 & 79 banks \\
\hline After Asian Financial Crisis & 1997 & 73 banks \\
& 1999 & 54 banks \\
\hline After Central Bank proposed major restructuring plan in February 2000 & 10 banks \\
& 2003 & 9 banks \\
& 2006 & 8 banks \\
\hline
\end{tabular}

(Source: Central Bank of Malaysia, 1980-2011 as cited in Ong \& Ng, 2013)

The causes of mergers and acquisitions are mostly to have a better performance in terms of finance and management. According to Shanmugam and Nair (2003), the reason why Malaysia banks merged together was to form a better baking system that is able to compete globally and more competitive. Other than that, the need to merge was also due to the pressure given by the World Trade Organization that demanded for financial liberalization from year 2003 (Shanmugam \& Nair, 2003). Though merging of strong banks with weak banks is to form a stronger and more competitive bank in global environment. However, the performance after the merging program may not be the way it was expected to be. Therefore, a need to investigate the performance of Malaysia domestic bank before and after acquisition is carried out. 
Table 2. First round of Malaysian Banks merger and acquisition (M\&A)

\begin{tabular}{|c|c|}
\hline Anchor Bank & Merger and Acquisition partner \\
\hline Malayan Banking Berhad (Maybank) & $\begin{array}{ll} & \text { The Pacific Bank Berhad } \\
\text { - } & \text { Phileo Allies Bank Berhad } \\
\text { - } & \text { Kewangan Bersatu Berhad }\end{array}$ \\
\hline Bumiputra-Commerce Bank Berhad & - $\quad$ Bank Bumiputra \\
\hline RHB Bank Berhad & $\begin{array}{ll}\text { - } & \text { Interfinance Berhad } \\
\text { - } & \text { Delta Finance Berhad } \\
\text { - } & \text { Bank Utama (Malaysia) Berhad } \\
\end{array}$ \\
\hline Public Bank Berhad & $\begin{array}{ll}\text { - } & \text { Hock Hua Bank Berhad } \\
\text { - } & \text { Advance Finance } \\
\text { - } & \text { Sime Merchant Bankers } \\
\end{array}$ \\
\hline Arab-Malaysian Bank & - $\quad$ MBF Finance Berhad \\
\hline Hong Leong Bank Berhad & $\begin{array}{ll}- & \text { Wah Tat Bank } \\
- & \text { Credit Corporation Malaysia } \\
\end{array}$ \\
\hline Alliance Bank & $\begin{array}{ll} & \text { International Bank Malaysia } \\
\text { - } & \text { Sabah Bank } \\
\text { - } & \text { Sabah Finance } \\
\text { - } & \text { Bolton Finance } \\
\text { - } & \text { Bumiputra Merchant Bankers } \\
\text { Amanah Merchant Bank }\end{array}$ \\
\hline Affin Bank & $\begin{array}{ll} & \text { BSN Commercial Bank } \\
\text { - } & \text { BSN Finance } \\
\text { - } & \text { BSN Merchant Bank } \\
\end{array}$ \\
\hline Southern Bank & $\begin{array}{ll}- & \text { Ban Hin Lee Bank } \\
\text { - } & \text { Perdana Finance } \\
\text { - } & \text { Cempaka Finance } \\
\text { - } & \text { United Merchant Finance } \\
\text { - } & \text { Perdana Merchant Bankers } \\
\end{array}$ \\
\hline EON Bank & $\begin{array}{ll}- & \text { Oriental Bank } \\
\text { - } & \text { City Finance } \\
\text { - } & \text { Perkasa Finance } \\
\text { - } & \text { Malaysia International } \\
\text { - } & \text { Merchant Bankers }\end{array}$ \\
\hline
\end{tabular}

(Source: Bank Negara Malaysia as cited in Sufian \& Abdul Majid, 2005)

According to Talha and Sallehhuddin (2005), several theories on value maximization of acquisition theory can be found such as diversification of risk theory, coinsurance effect theory, efficiency theory, merger and debt capacity, tax benefit theory, agency theory, asymmetric information theory, the monopolistic theory of acquisition, and perfectly competitive acquisition market theory. However, two theories stated in Talha and Sallehhuddin (2005) are chosen for this study which are diversification of risk theory and efficiency theory. The independent variables are financial ratios and event study, whereas the dependent variable is the performance on Domestic Malaysian banks.

Two methods were used in this study which are financial ratios and event study. Financial ratios are to find out the differences between before and after mergers and acquisition of 2 selected anchor banks. The event method is usually used to investigate whether shareholders are able to earn abnormal return. Event study is based on efficient market hypothesis. Therefore, whether investors are able to earn abnormal return may also be related to the form of market. There are three forms which are weak form, semi-strong form, and strong form. Financial ratios can be categorized into few groups which are liquidity, activity, leverage, profitability, and market. The use of financial ratios is to find out assess whether a firm is able to perform better after the merger and acquisition. Whereas, event study methodology is to find out whether shareholders are able to earn abnormal return after the announcement. The independent variables are the financial ratios and the event study. These two independent variables are to examine the performance of Malaysia domestic bank before and after merger and acquisition.

This research is organized by five sections. The introduction of the study is discussed in Section 1. Section 2 is the literature review which is going to discuss on various views of previous researches related to this article. Research methodology and data collection is going to be presented in Section 3, while Section 4 is concerning the result and the discussion on the result. Aconclusion is going to be discussed in the final section of this study, other than that, recommendations for future research and limitations for this research are going to be presented in the final section as well. 


\section{Research Objectives}

i. To examine the financial ratios of two anchor banks which are RHB Banks Berhad (acquired Bank Utama (Malaysia) Berhad) and Hong Leong Bank Berhad (acquired EON Bank Berhad).

ii. To investigate the abnormal return (AR), average abnormal return (AAR), cumulative average abnormal return (CAAR), and the t-statistics for both acquirer and being acquired banks.

iii. To investigate whether investors are able to earn an abnormal return after the event announcement.

\section{Literature Reviews}

Financial ratios can be one of the methods to assess a bank or company performance using the calculated percentage or ratios. Event study is used to find the abnormal return (AR), average abnormal return (AAR), cumulative average abnormal return (CAAR), and t-statistic to find out whether investors can earn abnormal return. However, two cases of acquisitions were chosen from the rest of the banks acquisitions as the annual report is needed in the financial ratios and historical prices is needed for the event study. Certain banks are not listed in Bursa Malaysia, therefore, no historical annual report can be retrieved. Other than that, certain banks which have been required may not be listed anymore, therefore, is difficult to retrieve the historical prices which is needed for event study.

\section{Financial Ratios}

Banks, financial institutions, or companies generally use financial ratios to assess the performance before and after mergers and acquisition to point out the weakness, whether after the mergers and acquisition they have better performance. According to Talha and Sallehhuddin (2005), by using total liability to total asset (TLOTA), total liabilities to equity (TLOE), times interest earned (TIE), and cash debt coverage ratio (CDCR) to analysis the impact or merger and acquisition on debt management ratio, the results shows that mergers and acquisition of Malaysia banks sector generally improve the debt management ratio. According to Said et al. (2008), findings using the method of financial ratios on 4 out of 9 mergers in America show that there was improvement in cost efficiency, however, the rest 5 mergers in America show no improvement. According to Ong and Ng (2013), the performance before and after mergers and acquisitions for Malaysia banks using financial ratios such as total debt ratio (TDR), debt to equity ratio (DTE), interest coverage ratio (ICR), return on assets (ROA), return on equity (ROE), and earnings per share (EPS) overall shows not much of significant relationship and not much improvement in term of leverage ratios and also the performance of Malaysia bank after the mergers and acquisition. According to Liargovas and Repousis (2011), this research in on Greek banking sector, by using financial ratios, the results shows that the Greek banking sector has low market shares. Thus, Financial ratios are commonly use to assess the performance of pre-merger and post-merger to find out whether a bank or financial institutions perform well after the merger.

\subsection{Event Study}

According to Liargovas and Repousis (2011), event study is based on the theory of efficient market hypothesis which was developed by Fama. In efficient market hypothesis $(\mathrm{EMH})$, there are three forms which are weak form, semi-strong form, and strong form of efficient market. Weak form reflects historical prices, semi-strong includes public available information, and strong form reflects both publicly and privately information. Generally, event study uses the "normal" and the "abnormal" return analysis which is calculated on asset pricing method basis. By using the event study methodology, Liargovas and Repousis found that the bidder banks have lower cumulative abnormal return than the targeted banks (Liargovas \& Repousis, 2011). According to Capron and Pistre (2002), event study can help in estimating the acquirer abnormal return and the result shows that in order for the acquirers to earn abnormal return, the corporate control have to be imperfectly competitive. According to Song and Walkling (2000), there are few implications of the acquisition probability hypothesis. First, targeted firms are able to earn positive abnormal returns. Second, there is a relationship between the average abnormal return of targeted firms with the degree of surprise correlated with the event announcement. Third, the cross-sectional difference is that the abnormal return of targeted firms is related to the variables of possibility of acquisition which means smaller firms has the largest probability of acquisition due to lower managerial ownership, big debt capacity, and slow growth. Last, targeted firms are able to gain more return after the acquisitions (Song \& Walkling, 2000).

\section{Data and Methodology}

This study is conducted to examine the performance of two anchor Malaysian domestic banks before and after acquisitions by using financial ratios and e vent study to find out whether acquisitions really help in having better performance than not undergoing acquisitions. Secondary data was used for this research such as annual report, 
historical prices, and Kuala Lumpur Stock Exchange index (KLSE). Two cases were cho sen for this study which is RHB bank Berhad with Bank Utama (Malaysia) Berhad and Hong Leong Bank Berhad with EON Bank Berhad. And the period of study is 2 years before and 2 years after the merger and acquisition. The chosen two anchor banks were Hong Leong Bank Berhad acquired EON Bank in year 2011 and RHB Bank Berhad was the last acquisition activity in year 2000. The period of time for RHB Bank Berhad and Bank Utama (Malaysia) Berhad is from year 2001 to 2005. As for Hong Leong Bank Berhad and EON Bank Berhad, the period is 2009 to 2013. The annual report was used for the financial ratios part to find out the difference between before and after merger and acquisition. The financial ratios and event study have the possibility to examine the performance of Domestic Malaysian banks before and after the acquisition. For the event study, the null hypothesis will be rejected if the $t$-statistic is larger than the critical value at $1 \%$ or $5 \%$ level of significance.

There are different categories of financial ratios. However, not all the financial ratios are used in this study. The selected financial ratios to examine the performance of Malaysia domestic bank before and after merger and acquisition are Return on assets (ROA), Return on equity (ROE), Earnings per Share (EPS), Return on capital employed (ROCE) , Earnings before interest and tax/ total assets (EBITOTA), Debt-to-equity ratio (DER), Total liability to total assets (TLOTA), Total liabilities to equity (TLOE), and Longer-term debt to total assets (LTDOTA). These are determined by the following formula;

Table 3. Formulas for selected financial ratios

\begin{tabular}{cl}
\hline Dependent Variables & Formulas \\
\hline Return on equity (ROE) & $=\frac{\text { Net income }}{\text { Stockholders' equity }} \times 100$ \\
\hline Return on total asset (ROA) & $=\frac{\text { Net income }}{\text { Total assets }} \times 100$ \\
\hline Earnings per share (EPS) & $=\frac{\text { Net profit }}{\text { Average outstanding shares }} \times 100$ \\
\hline Independent Variables &
\end{tabular}

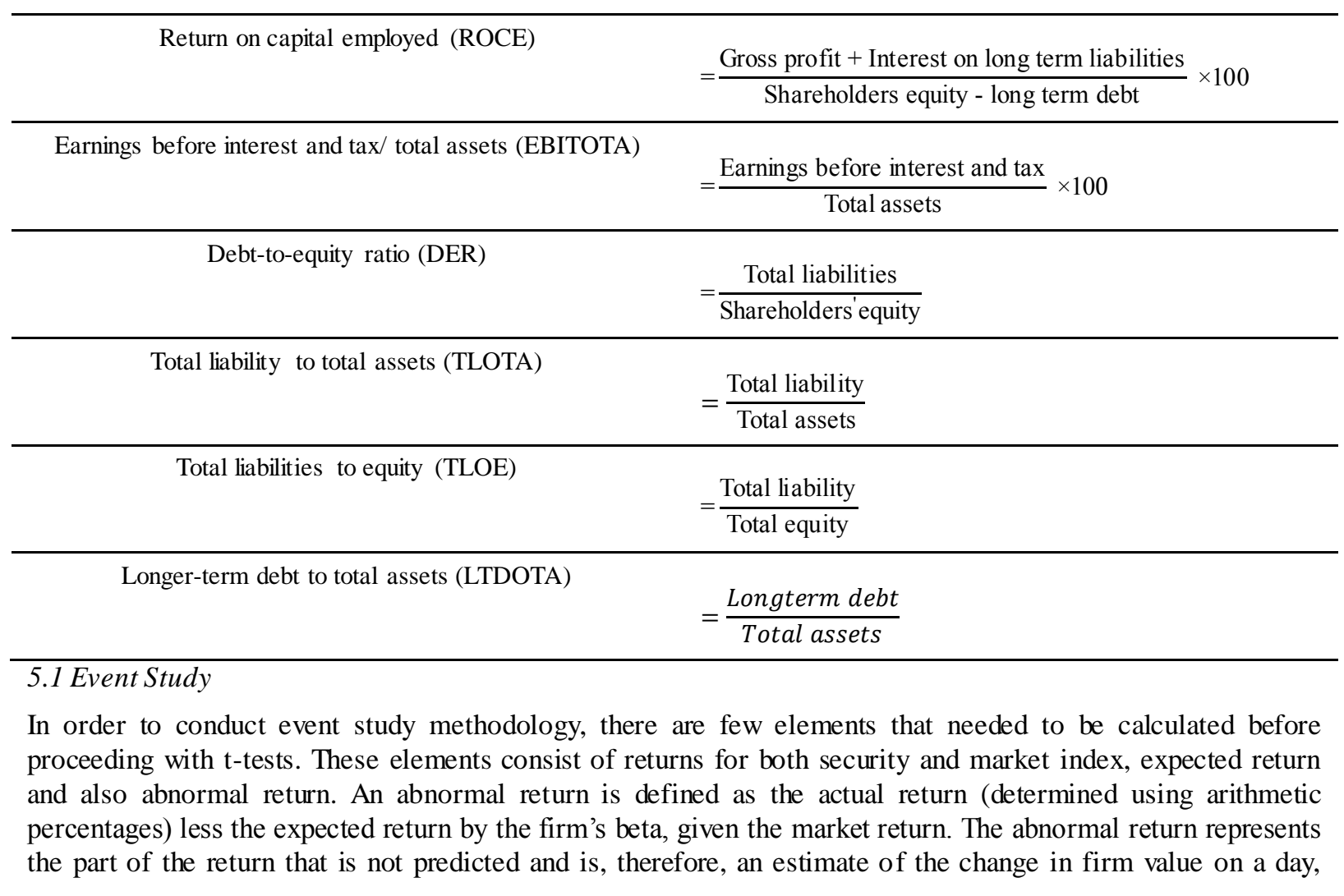


which is caused by the event (merger announcement). The expected return represents the return that would be expected if no event took place. The firm's beta is measured over an estimation period of 216 days prior to event window and the actual return is measured over a period of 10 days before and after the announcement date (event window of 21 days and announcement date is designated as day 0 in event window). The Figure 1 shows the timeline for event study.

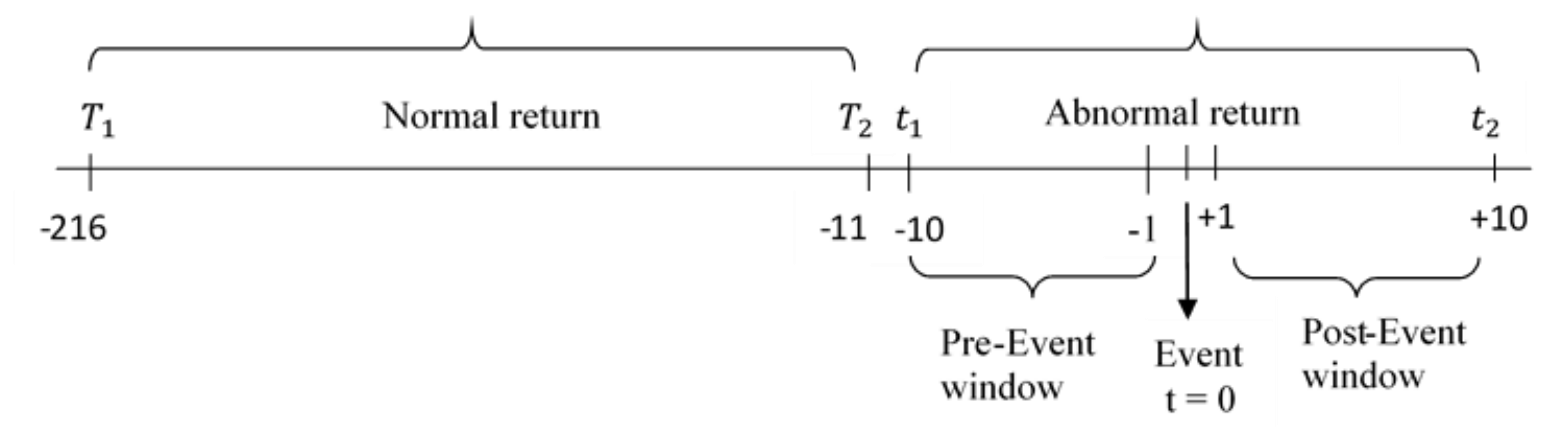

Figure 1. Timeline for event study

Event window represents possible leakages of information before merger is announced and possible stock price reactions after merger is announced and it finally captures all the effects on stock prices of the event. The merger announcement date, daily stock prices, daily Kuala Lumpur Composite Index, as well as information about the merger and acquisition, was mainly collected from Bursa Saham website and Yahoo Finance. The impact of an event can be estimated by measuring the abnormal return. The abnormal return is the difference between the return and the expected return over the event window. Firstly, daily returns of each securities price were calculated over the estimation window and event window using the equation below:

$$
R_{t}=\frac{l_{t}-l_{t-1}}{l_{t-1}} \times 100
$$

Where,

$R_{t}=$ stock daily rate of return on $\mathrm{t}$ day,

$l_{t}=$ stock closing value on $\mathrm{t}$ day,

$l_{t-1}=$ stock index closing value on $\mathrm{t}-1$ day.

To calculate expected return, the Market Model Method is used. It is the most widely used method in event study literature because the Market Model takes explicit account of the risk associated with the market and mean

returns. It is estimated by running the following regression over estimation period by using Ordinary Least Squared (OLS) model:

Where,

$$
R_{i t}=\alpha_{i t}+\beta_{i t} R_{m t}+e_{i t}
$$

$$
\begin{aligned}
& R_{i t}=\text { return on security } i \text { for day } \mathrm{t}, \\
& R_{m t}=\text { return on KLCI for day } \mathrm{t}, \\
& \alpha_{i t}=\text { intercept for security } i \text { for day } \mathrm{t}, \\
& \beta_{i t}=\text { slope for security } i \text { for day } \mathrm{t}, \\
& e_{i+}=\text { error term for securitv } i
\end{aligned}
$$

Parametric tests were carried out for Average Abnormal Returns (AARs) and Cumulative Average Abnormal Returns (CAARs). AARs refers to average abnormal return and CAARs represent the average total effect of the event across all firms over a specified time interval. Two cases of mergers and acquisitions and use $t$-test and hypotheses:

Hypothesis 1: $\mathrm{Ho}: \mathrm{AAR}=0$ and $\mathrm{H} 1: \mathrm{AAR} \neq 0$

Hypothesis 2: Ho: $\mathrm{CAAR}=0$ and $\mathrm{H} 1: \mathrm{CAAR} \neq 0$ 
The $\mathrm{H}_{\mathrm{o}}$ hypothesis tests if stocks that are affected by the event act will not experience Average Abnormal Returns or Cumulative Average Abnormal Returns and $\mathrm{H}_{1}$ hypothesis tests if stocks that are affected by the event act will experience negative or positive Average Abnormal Returns or Cumulative Average Abnormal Returns, where each abnormal security return is normalized by its estimation period standard deviation. Analytically:

$$
t_{A A R}=\frac{\mathrm{AAR}_{\mathrm{t}}}{\mathrm{S}\left(\mathrm{AAR}_{\mathrm{t}}\right)}
$$

Then, standard deviation is estimated as

$$
S(A A R)=\sqrt{\sum_{t=1}^{T_{0}} \frac{\sum A A R_{t}^{2}}{T_{0}-1}}
$$

Where,

$$
T_{0} \quad=\text { number of days in the estimation period. }
$$

The t-test assumes that the individual abnormal returns are cross-sectionally independent and identically distributed. Also estimate $t$-statistic for CAARs by dividing CAARs with standard deviation:

$$
\mathrm{t}_{\mathrm{CAAR}}=\frac{\mathrm{t}_{\mathrm{CAAR}}}{\sqrt{\mathrm{T}^{*} \mathrm{~S}(\mathrm{AAR})}}
$$

If statistic tests show that $\mathrm{t}$-statistic is higher or equal to a crucial price, then null hypotheses will be rejected which means that AARs or CAARs will be statistically signific ant.

\section{Findings and Discussion}

The Domestic Malaysian banks, RHB Bank Berhad and Hong Leong Bank Berhad, are chosen based on the occurrence of acquisition after year 2000. The performance of selected Malaysian domestic banks before and after the event is shown in tables and figures. Relevant financial ratios are used to investigate the performance of the Malaysian domestic banks of pre- and post- acquisition. The event study is being used in this research to find out the Abnormal return (AR), Average Abnormal Return (AAR), Cumulative Average Abnormal Return (CAAR), and the t-statistics.

\subsection{Empirical Results for Financial Ratios}

The financial ratios which are used to assess the performance and capital structure of 2 chosen Malaysian domestic banks 2 years before and 2 years after the acquisition and acquisition are return on equity (ROE), return on total assets (ROA), earnings per share (EPS), return on capital employed (ROCE), earnings before interest and tax (EBITOTA), debt-to-equity ratio (DER), total liability to total assets (TLOTA), total liabilities to equity (TLOE), and longer-term debt to total assets (LTDOTA). The following table shows the summary results on the performance of 2 selected Malaysian domestic banks 2 years before and 2 years after acquisition using the financial ratios.

From table 4, there was an increment for the ROE, ROCE, EPS, EBITOTA, and DER. ROE indicates the management's performance (Brigham and Houston, 2007). The higher the ROE means the surplus funds can be invested to improve business operations without having additional investment of capital from shareholders (Graham and Zweig, 2003).

This increment of ROE shows RHB bank is efficiently generating income on new investment. A higher ROCE indicates more efficient use of capital. This increase in ROCE shows that the firm is generating profit. Earnings per share (EPS) indicate how much earnings has been generated per share of stock during the reported period. As a firms earnings increase, earnings per share looks better and the firm releasing more shares increases the number of shares outstanding (Gyimah and Oscar, 2011). This increment in EPS shows that the new bank is improving in the earning power. The EBITOTA shows an increment after the acquisition, which means the new bank, is generating stable operating income. The increment of DER shows that is not a good sign as it indicate that the new bank is borrowing a big proportion of asset from other financial institutions. 
Table 4. Summary of financial ratio before and after the merger of RHB Bank Berhad and Bank Utama (Malaysia) Berhad

\begin{tabular}{|c|c|c|c|c|c|c|c|c|c|c|}
\hline \multirow[b]{3}{*}{$\begin{array}{l}\text { Financial } \\
\text { ratios }\end{array}$} & \multicolumn{6}{|c|}{ Pre-acquisition } & & \multirow{2}{*}{\multicolumn{3}{|c|}{$\begin{array}{c}\text { Post-acquisition } \\
\text { RHB Bank Berhad }\end{array}$}} \\
\hline & \multicolumn{3}{|c|}{ RHB Bank Berhad } & \multicolumn{3}{|c|}{$\begin{array}{c}\text { Bank Utama (Malaysia) } \\
\text { Berhad }\end{array}$} & \multirow{11}{*}{$\begin{array}{c}\text { Merge } \\
\text { in } \\
2003\end{array}$} & & & \\
\hline & $\begin{array}{l}2001 \\
(\mathrm{RM} \\
000)\end{array}$ & $\begin{array}{l}2002 \\
\text { (RM } \\
\text {,000) }\end{array}$ & Average & $\begin{array}{l}2001 \\
\text { (RM } \\
000)\end{array}$ & $\begin{array}{l}2002 \\
(\mathrm{RM} \\
000)\end{array}$ & Average & & $\begin{array}{c}2004(\mathrm{RM} \\
, 000)\end{array}$ & $\begin{array}{c}2005(\mathrm{RM} \\
, 000)\end{array}$ & Average \\
\hline $\mathrm{ROE}$ & $58.65 \%$ & $56.22 \%$ & $57.44 \%$ & $12.70 \%$ & $13.03 \%$ & $12.87 \%$ & & $77.14 \%$ & $56.89 \%$ & $67.02 \%$ \\
\hline ROA & $3.58 \%$ & $3.54 \%$ & $3.56 \%$ & $1.28 \%$ & $12.03 \%$ & $6.65 \%$ & & $3.96 \%$ & $2.84 \%$ & $3.4 \%$ \\
\hline EPS & $0.11 \%$ & $0.20 \%$ & $0.155 \%$ & $0.02 \%$ & $0.04 \%$ & $0.03 \%$ & & $0.18 \%$ & $0.14 \%$ & $0.16 \%$ \\
\hline ROCE & $49.81 \%$ & $49.54 \%$ & $49.68 \%$ & $27.05 \%$ & $24.54 \%$ & $25.80 \%$ & & $59.13 \%$ & $41.11 \%$ & $50.12 \%$ \\
\hline EBITOTA & $1.08 \%$ & $0.70 \%$ & $0.89 \%$ & $0.20 \%$ & $6.16 \%$ & $3.18 \%$ & & $1.06 \%$ & $0.77 \%$ & $0.92 \%$ \\
\hline DER & 15.37 & 14.88 & 15.13 & 8.89 & 1.02 & 4.96 & & 18.27 & 18.77 & 18.52 \\
\hline TLOTA & 18.27 & 18.77 & 18.52 & 0.94 & 0.94 & 0.94 & & 0.94 & 0.94 & 0.94 \\
\hline TLOE & 0.90 & 0.50 & 0.7 & 0.50 & 0.90 & 0.70 & & 18.77 & 18.27 & 18.52 \\
\hline LTDOTA & 14.88 & 15.37 & 15.13 & 0.0095 & 0.0135 & 0.0115 & & 0.0081 & 0.0060 & 0.0071 \\
\hline
\end{tabular}

There was a decrease in ROA, TLOTA, and LTDOTA. ROA ratio is used to measure how much profit the company can generate with each dollar of assets. The higher ROA indicate the company is performing well (Brigham and Houston, 2007). But there is a decrease in ROA and it shows that the new bank uses a great deal of debt in which the high interest rate expenses cause the net income to be relatively low. TLOTA is also known as a debt ratio. Decrease in TLOTA shows a good sign as the new bank does not rely much on debt and the asset and equity is higher than the liabilities. Decrease in LTDOTA suggests that the firm has lesser outstanding loans as compared to total assets that it owns.

From table 5, there was a decrement for the ROE, ROA, ROCE, DER, TLOTA and TLOE. This decrement on ROE shows that the new bank is efficiently not generating much income on new investment.

Table 5. Summary of financial ratio before and after the merger of Hong Leong Bank Berhad and EON Bank Berhad

\begin{tabular}{|c|c|c|c|c|c|c|c|c|c|c|}
\hline \multirow[b]{3}{*}{$\begin{array}{l}\text { Financial } \\
\text { ratios }\end{array}$} & \multicolumn{6}{|c|}{ Pre-acquisition } & \multirow{12}{*}{$\begin{array}{l}\text { Merge } \\
\text { in } \\
2011\end{array}$} & \multirow{2}{*}{\multicolumn{3}{|c|}{$\begin{array}{c}\text { Post-acquisition } \\
\text { Hong Leong Bank Berhad }\end{array}$}} \\
\hline & \multicolumn{3}{|c|}{ Hong Leong Bank Berhad } & \multicolumn{3}{|c|}{ EON Bank Berhad } & & & & \\
\hline & $\begin{array}{l}2009 \\
\text { (RM } \\
000)\end{array}$ & $\begin{array}{l}2010 \\
(\mathrm{RM} \\
000)\end{array}$ & Average & $\begin{array}{l}2009 \\
\text { (RM } \\
000)\end{array}$ & $\begin{array}{l}2010 \\
(\mathrm{RM} \\
000)\end{array}$ & Average & & $\begin{array}{c}2012^{*} \\
\text { (RM' } \\
\text { Million) }\end{array}$ & $\begin{array}{c}\mathbf{2 0 1 3}^{*} \\
\text { (RM' } \\
\text { Million) }\end{array}$ & Average \\
\hline ROE & $15.86 \%$ & $15.38 \%$ & $15.62 \%$ & $40.39 \%$ & $42.62 \%$ & $41.51 \%$ & & $15.61 \%$ & $14.24 \%$ & $14.93 \%$ \\
\hline ROA & $10.68 \%$ & $12.45 \%$ & $10.56 \%$ & $3.09 \%$ & $3.18 \%$ & $3.14 \%$ & & $1.10 \%$ & $1.13 \%$ & $1.12 \%$ \\
\hline EPS & $62.43 \%$ & $68.15 \%$ & $60.29 \%$ & $49.21 \%$ & $63.49 \%$ & $56.35 \%$ & & $104.97 \%$ & $105.81 \%$ & $105.39 \%$ \\
\hline ROCE & $24.39 \%$ & $21.89 \%$ & $23.14 \%$ & $27.23 \%$ & $28.46 \%$ & $27.85 \%$ & & $22.83 \%$ & $19.70 \%$ & $21.27 \%$ \\
\hline EBITOTA & $1.34 \%$ & $1.49 \%$ & $1.42 \%$ & $0.91 \%$ & $1.11 \%$ & $1.01 \%$ & & $1.41 \%$ & $1.46 \%$ & $1.44 \%$ \\
\hline DER & 12.91 & 12.19 & 12.55 & 12.05 & 12.41 & 12.23 & & 12.51 & 11.55 & 12.03 \\
\hline TLOTA & 0.87 & 0.99 & 0.93 & 0.92 & 0.93 & 0.93 & & 0.93 & 0.92 & 0.925 \\
\hline TLOE & 12.91 & 12.19 & 12.55 & 12.05 & 12.41 & 12.34 & & 12.51 & 11.55 & 12.03 \\
\hline LTDOTA & 0.0019 & 0.0013 & 0.0016 & 0.0039 & 0.0044 & 0.0042 & & 0.0019 & 0.0019 & 0.0019 \\
\hline
\end{tabular}

Decrease in ROA shows that the new bank uses a great deal of debt in which the high interest rate expenses cause the net income to be relatively low. Decrease in ROCE shows that the firm is not generating much profit. The decrement of DER shows that the new bank is not relying on external funds. Decrement in TLOTA and TLOE is a good sign as the new bank does not rely much on debt and it shows that the asset and equity is higher than the liabilities.

There was an increase in EPS, EBITOTA, and LTDOTA. Increase in EPS shows that the new bank is improving in the earning power. The EBITOTA shows an increment after the acquisition, which means the new bank is generating stable operating income. Increment in LTDOTA suggests that the firm has a high an outstanding loan as compared to total assets that it owns.

\subsection{Results of Event Study}

The used of event study is to investigate whether to reject the null hypothesis $\left(\mathrm{H}_{0}\right)$ at a certain level of significant. In this section, the results of abnormal return (AR), average abnormal return (AAR), and cumulative abnormal return (CAAR), and t-statistic are shown in the form of tables and figures. 


\subsection{Abnormal Return (AR)}

The two tables as follow show the abnormal returns for the 2 selected Domestic Malaysian banks and the targeted banks during the event window.

From Table 6, it shows the abnormal return for RHB Bank and Bank Utama. RHB Bank shows more negative abnormal return than Bank Utama. Before the announcement on average, RHB Bank has more negative value compare to Bank Utama. On the day of the announcement, RHB Bank has yet to show a positive value. Bank Utama on the other hand, shows a positive AR on the day of the announcement with 1.3183. After the announcement, Bank Utama outperforms RHB bank as the AR for Bank Utama increase after the day of the announcement. Bank Utama has its highest AR on the 10th day after the event announcement. For RHB Bank, reject the null hypothesis at $5 \%$ level of significance for the 5th day before the announcement and on the day of the announcement and the 1st day to the 10th day after the announcement. The t-statistic shows a negative value, therefore, they have a negative relationship which means the stock price decreases after the announcement. As for Bank Utama the stock prices increase as reject the null hypothesis at 5\% level of significance. There is a positive relationship between the stock price and after the event announcement.

Table 6. Abnormal return (AR) for RHB Bank Berhad and Bank Utama (Malaysia) Berhad

\begin{tabular}{|c|c|c|c|c|}
\hline \multirow{2}{*}{ Event Window } & \multicolumn{2}{|c|}{ RHB Bank Berhad } & \multicolumn{2}{c|}{ Bank Utama (Malaysia) Berhad } \\
\cline { 2 - 5 } & AR & t-statistic & AR & t-statistic \\
\hline-10 & 0.5917 & -0.0808 & 0.3878 & 0.7866 \\
\hline-9 & -0.1126 & -0.1933 & -0.5828 & 0.2039 \\
\hline-8 & 0.3400 & 0.1467 & 1.6648 & 1.8686 \\
\hline-7 & -0.5193 & -0.3726 & -1.3220 & 0.5467 \\
\hline-6 & -0.5201 & -0.8927 & 1.5716 & $2.1183^{*}$ \\
\hline-5 & -1.8206 & $-2.7133^{*}$ & -1.7348 & 0.3835 \\
\hline-4 & 1.3422 & -1.3711 & 0.8697 & 1.2532 \\
\hline-3 & -0.7052 & -2.0763 & 1.4747 & $2.7279^{*}$ \\
\hline-2 & -0.4471 & $-2.5234^{*}$ & -2.7562 & -0.0283 \\
\hline-1 & -0.4688 & $-2.9922^{*}$ & 0.6388 & 0.6106 \\
\hline 0 & $-\mathbf{0 . 1 9 0 7}$ & $-\mathbf{3 . 1 8 3 0 ^ { * }}$ & $\mathbf{1 . 3 1 8 3}$ & $\mathbf{1 . 9 2 8 9}$ \\
\hline 1 & 0.3985 & $-2.7845^{*}$ & -0.7248 & 1.2041 \\
\hline 2 & -0.3819 & $-3.1663^{*}$ & 1.6813 & $2.8853^{*}$ \\
\hline 3 & -0.7318 & $-3.8981^{*}$ & 0.9657 & $3.8510^{*}$ \\
\hline 4 & 0.6901 & $-3.2080^{*}$ & -0.0286 & $3.8224^{*}$ \\
\hline 5 & -1.2627 & $-4.4706^{*}$ & -0.3963 & $3.4262^{*}$ \\
\hline 6 & 1.8109 & $-2.6598^{*}$ & -0.2524 & $3.1738^{*}$ \\
\hline 7 & -0.4832 & $-3.1430^{*}$ & 0.6221 & $3.7959^{*}$ \\
\hline 8 & -1.0274 & $-4.1704^{*}$ & -0.7526 & $3.0433^{*}$ \\
\hline 9 & -2.7325 & $-6.9029^{*}$ & -1.9651 & 1.0782 \\
\hline 10 & 1.3508 & $-5.5520^{*}$ & 2.9650 & $4.0432^{*}$ \\
\hline
\end{tabular}

(* reject $H_{0}$ at $5 \%$ level of significant)

Table 7 below shows the abnormal return and t-statistic computed for Hong Leong Bank Berhad. On the event day, the company abnormal return is 0.6642 which means that the company is generating an above average return. However, from the $\mathrm{t}$-value of 0.6758 , there was not enough statistical evidence to reject the null hypothesis which is the stock price was no affected by the event. On day $t=1$, which is the day after the announcement is made by EON Bank, Hong Leong Bank still show a positive abnormal return trend and it becomes the higher value after the announcement. This indicates that the company stock prices increase after the announcement. After that, the abnormal return decrease on $t=2$ but still showing a positive value and increase again on $\mathrm{t}=3$. This increasing trend has remained until on the days 5 after the announcement. After the announcement on days 5 , this value is slightly decreased until it becomes the negative value. The decreasing trend and negative value of abnormal return for Hong Leong Bank Berhad shows that the company generating returns which is below the market return.

As refer to the $t$-statistic as shown in table 7 , on day $t=1$, Hong Leong Bank stock price start to react to the announcement. There is enough statistical evidence to reject null hypothesis at 5 percent significant level when it is on the $t=2$ days because the $t$ statistic which 2.4429 is larger than the 1.96 or $5 \%$ level of significance. Again, the stock price is highly reacting positively towards the announcement. 
Table 7. Abnormal return (AR) for Hong Leong Bank Berhad and EON Bank Berhad

\begin{tabular}{|c|c|c|c|c|}
\hline \multirow{2}{*}{ Event Window } & \multicolumn{2}{|c|}{ Hong Leong Bank Berhad } & \multicolumn{2}{c|}{ EON Bank Berhad } \\
\cline { 2 - 5 } & AR & t-statistic & AR & 0.1254 \\
\hline-10 & -0.1553 & -0.1580 & -0.0137 & -0.0219 \\
\hline-9 & -0.2198 & -0.2236 & -0.0022 & -0.0036 \\
\hline-8 & -1.6387 & -1.6672 & 0.5682 & 0.9106 \\
\hline-7 & -1.1997 & -1.2206 & 0.9853 & 1.5789 \\
\hline-6 & 0.1920 & 0.1953 & 0.7037 & 1.1277 \\
\hline-5 & 0.2222 & 0.2261 & -0.0061 & -0.0098 \\
\hline-4 & -0.0285 & -0.0290 & 2.1996 & $3.5249^{*}$ \\
\hline-3 & 0.3430 & 0.3490 & -0.5537 & -0.8873 \\
\hline-2 & -1.0257 & -1.0436 & -0.0223 & -0.0357 \\
\hline-1 & 1.3392 & 1.3625 & $\mathbf{0 . 6 6 1 6}$ & $\mathbf{1 . 0 6 0 2}$ \\
\hline $\mathbf{0}$ & $\mathbf{0 . 6 6 4 2}$ & $\mathbf{0 . 6 7 5 8}$ & 1.8959 & $3.0381^{*}$ \\
\hline 1 & 7.0045 & $7.1265^{*}$ & -0.2612 & -0.4186 \\
\hline 2 & 2.4010 & $2.4429^{*}$ & 0.1575 & 0.2524 \\
\hline 3 & 3.7430 & $3.8082^{*}$ & -0.0140 & -0.0224 \\
\hline 4 & 0.4982 & 0.5069 & 0.0145 & 0.0232 \\
\hline 5 & 2.6178 & $2.6634^{*}$ & -0.0157 & -0.0251 \\
\hline 6 & -1.0797 & -1.0986 & 0.8032 & 1.2871 \\
\hline 7 & -1.4746 & -1.5003 & 0.0011 & 0.0018 \\
\hline 8 & -1.0290 & -1.0469 & -0.0122 & -0.0196 \\
\hline 9 & 0.1217 & 0.1238 & -0.1650 & -0.2645 \\
\hline 10 & -1.3547 & -1.3783 & & \\
\hline
\end{tabular}

(* reject $H_{0}$ at $5 \%$ level of significant)

This indicates that the investors are happy and confidence with the takeover decision. The investors believe that the takeover can help the company to stand a position in the highly competitive banking world. As can be seen in the table 7 above, Hong Leong Bank Berhad stock price fluctuated before the event day. On $t=-10$ day, the company is showing a negative abnormal return. Although the abnormal return turn to positive on $t=-6$ and $t=-5$ day, but it drops to negative value again on $t=-4$ day. However, one trading days before the announcement is made the company abnormal returns show a positive value which is 1.3392 . Although the increase of share price does not big until affect the $t$-value, but since it is near to the event day, so it cannot be denied that part of the investor actually identify something and start to invest before the stock price go up after the announcement is made.

From Eon Bank abnormal return before announcement, the stock performance of the EON bank actually is good as the abnormal return are mostly in the positive value although the value does not seen higher than after the announcement is made. As shown in table 7, the company has a negative abnormal return of -0.01368 of $t=-9$ day, -0.00222 on days $-8,-0.00609$ on $\mathrm{t}=-4$ day, -0.55366 on $\mathrm{t}=-2$ and -0.02227 on $\mathrm{t}=-1$. On $\mathrm{t}=-10$ day, the company is showing a positive abnormal return of 0.12539 and same goes to $t=-7$ day, which the company start to show a positive abnormal return of 0.568229 before it go to negative abnormal return on $t=-4$ day. Moreover, the company's abnormal return go back to normal which is 2.199601 on $\mathrm{t}=-3$ day and on this day the abnormal return reach a maximum point among other trading day before the announcement. On day $t=1$, which is the day after the announcement, reject the null hypothesis at 5\% level of significance as the t-value if 3.0381. This shows that the investors are giving a good response to the announcement.

\subsection{Average Abnormal Return (AAR)}

As for average abnormal return (AAR), it is shown in the following tables and figures. The tables and figures shows the average abnormal returns (AARs) for the 2 selected domestic Malaysia banks with the targeted banks across the event period.

From the Figure 2 below, it shows that AAR for RHB Bank Berhad is going downwards. On the other hand, the AAR for Bank Utama is fluctuating gradually. This shows that the shareholders for RHB Bank were not able to earn abnormal return for the period of $(-10,10)$. On the $6^{\text {th }}$ day after the event, the AAR for RHB Bank began to drop dramatically until the $9^{\text {th }}$ day after the event. 


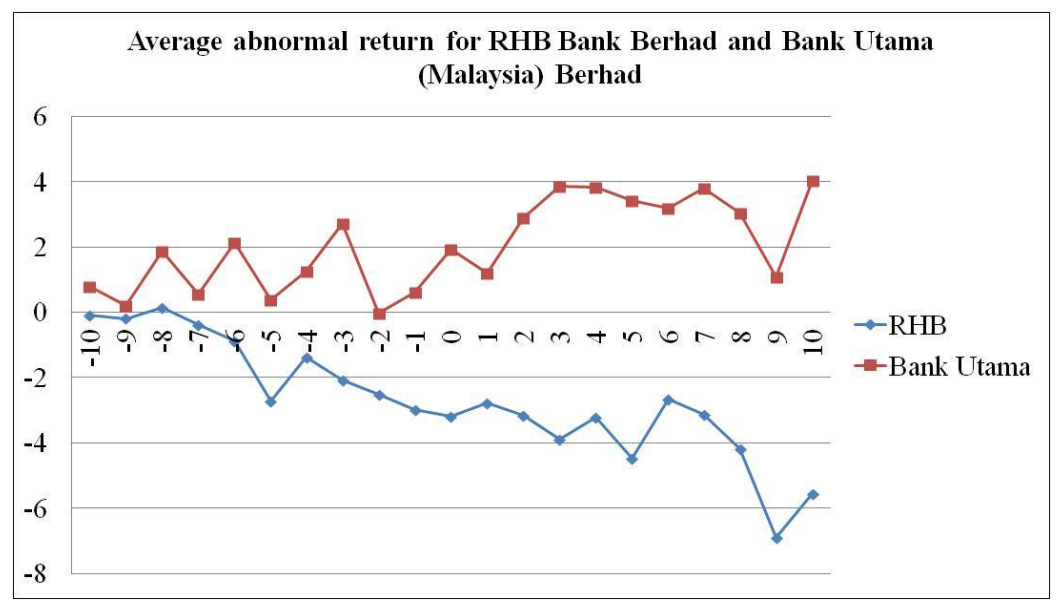

Figure 2. Average abnormal return (AAR) for RHB Bank Berhad and Bank Utama (Malaysia) Berhad

Before the event announcement, RHB Bank was able to perform better and the shareholders were able to earn abnormal return but after the event. As for Bank Utama, after the event announcement the AAR for Bank Utama began to increase from day 1 after the announcement to day 4 . Although the AAR drop from the $6^{\text {th }}$ day to the $9^{\text {th }}$ day, the AAR increase back again on the $10^{\text {th }}$ day after the event announcement.

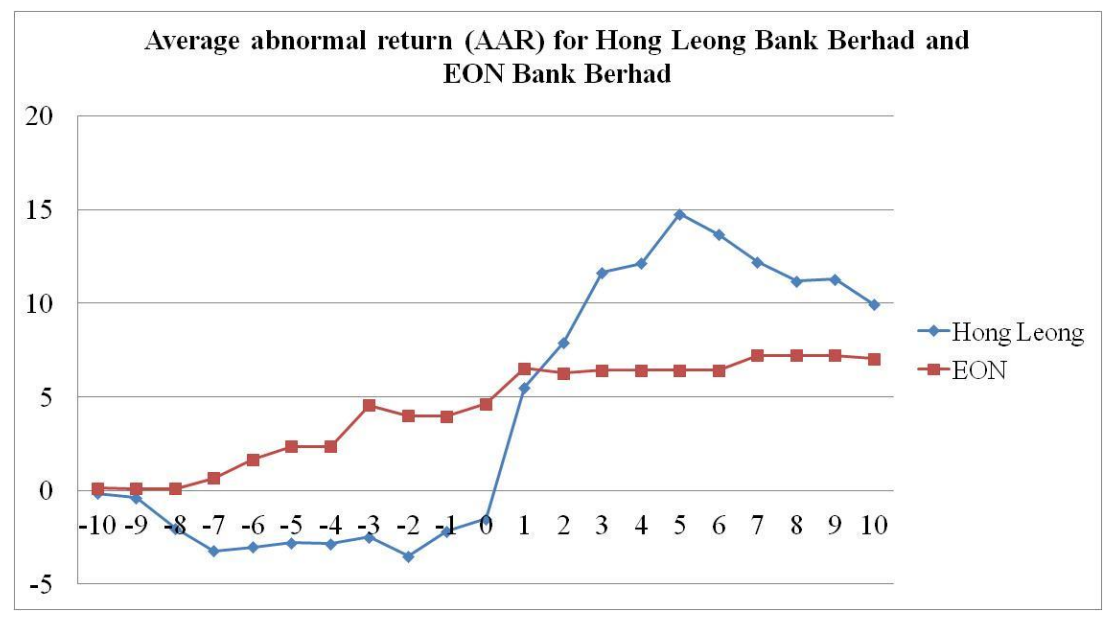

Figure 3. Average abnormal return (AAR) for Hong Leong Bank Berhad and EON Bank Berhad

As refer to the Figure 3 above, it shows that the EON Bank has a more stable average abnormal return than Hong Leong Bank before the acquisition. EON Bank shows a consistent positive value for AAR before the event announcement. However, it was different for Hong Leong Bank as it shows more negative AAR than EON Bank before the event announcement. There is a big difference between the highest average abnormal return for EON Bank Berhad and Hong Leong Bank Berhad before the announcement date. For example, the highest average abnormal return for EON Bank Berhad is on day $t=-3$ (4.560234) and it is in a positive value while the highest average abnormal return for Hong Leong Bank Berhad is on $t=-10$ day $(-0.15526)$ but it is in a negative value. Through this circumstance, it can be said that the performance for EON Bank Berhad before the announcement is better the performance for Hong Leong Bank Berhad. After the event announcement, Hong Leong Bank is performing better than EON Bank. Hong Leong Bank shows a higher value of AAR than EON Bank. The higher average abnormal return for Hong Leong Bank after the announcement was 14.75757 which also represent the maximum point among the 21 days of trading, whereas, the highest point for EON Bank was 7.227188. Overall, the performances for both banks were considered better than before the event announcement.

\subsection{Cumulative Average Abnormal Return (CAAR)}

The cumulative average abnormal return (CAAR) for the 2 selected Malaysian domestic banks and the targeted banks are presented in a table form which is as follow.

Table 8 shows the cumulative average abnormal return for RHB Bank Berhad and Bank Utama (Malaysia) Berhad. The cumulative residual for a stock price for each day is the actual day stock price residual plus the prior 
day of cumulative residual. From Table 8 , it shows that the on the day of the announcement $(-1,0)$ RHB Bank has a negative abnormal return of -6.1752 . The Table 8 also shows that for the event period of $(-10,+10),(-10$, $-1),(-1,0),(-1,+1),(0,+1)$, and $(+1,+10)$ for RHB Bank, all of it shows a negative value, on the other hand, Bank Utama (Malaysia) shows a rather better result of CAARs than RHB Bank with all positive value. According to the t-test rejection rule, reject null hypothesis if $\mathrm{t}$-statistic is higher than $\mathrm{t}$-critical value. Therefore, from the Table 8 , reject the null hypothesis for $(-10,+10)$ and $(0,+1)$ for RHB Bank and Bank Utama at $5 \%$ level of significance. It can be concluded that although $(0,+1)$ was rejected, because it was the first day after the event announcement, it cannot be concluded that the mergers and acquisitions of RHB Bank with Bank Utama has no improvement as it takes times. As the new bank has just been established, the shareholders may not be able to obtain the latest information yet even though it is made public.

Table 8. Cumulative average abnormal return (CAAR) for RHB Bank Berhad and Bank Utama (Malaysia) Berhad

\begin{tabular}{lcccc}
\hline & \multicolumn{2}{c}{ RHB Bank Berhad } & \multicolumn{2}{c}{ Bank Utama (Malaysia) Berhad } \\
\cline { 2 - 5 }$(-10,+10)$ & CAAR & CAAR t-test & CAAR & CAAR t-test \\
$(-10,-1)$ & -56.2076 & $-5.9569^{*}$ & 42.7233 & 1.2610 \\
$(-1,0)$ & -13.0692 & -1.3851 & 10.4710 & 0.3058 \\
$(-1,+1)$ & -6.1752 & -0.6545 & 2.5395 & 0.3773 \\
$(0,+1)$ & -5.9674 & -0.6324 & 3.1330 & $3.6517^{*}$ \\
$(+1,+10)$ & -39.9555 & $-4.2345^{*}$ & 30.3233 & 0.4508 \\
\hline
\end{tabular}

(* reject Ho at $5 \%$ level of significant)

Table 9. Cumulative average abnormal return (CAAR) for Hong Leong Bank Berhad and EON Bank Berhad

\begin{tabular}{lcccc}
\hline & \multicolumn{2}{c}{ Hong Leong Bank Berhad } & \multicolumn{2}{c}{ EON Bank Berhad } \\
\cline { 2 - 5 }$(-10,+10)$ & CAAR & CAAR t-test & CAAR & CAAR t-test \\
$(-10,-1)$ & 9.9412 & 1.0530 & 7.0499 & 1.5660 \\
$(-1,0)$ & -2.1712 & -0.2300 & 3.9843 & 0.8851 \\
$(-1,+1)$ & 2.0034 & 0.2122 & 0.6393 & 0.1420 \\
$(0,+1)$ & 7.6687 & 0.8123 & 2.5575 & 0.5681 \\
$(+1,+10)$ & 11.4482 & 1.2126 & 2.4040 & 0.5340 \\
\hline
\end{tabular}

(* reject $\mathrm{H}_{\mathrm{o}}$ at $5 \%$ level of significant)

From Table 9, it shows that the CAARs value for both banks has more positive value than negative value. The only negative CAAR is on $(-10,-1)$ for Hong Leong Bank. The highest CAAR between these two banks is Hong Leong Bank $(0,+1)$ with 11.4482 . As all the t-statistic is lower than the critical value, do not reject the null hypothesis at $5 \%$ level of significance. This shows that shareholders were able to earn abnormal return during that period of time. However, on the $(-10,-1)$, Hong Leong has a negative value with -2.1712 and EON Bank has a positive value with 3.9843 which shows that on $(-10,-1)$ the shareholders for EON Bank were able to earn higher abnormal return than Hong Leong shareholder.

\section{Limitations of Study}

There were several limitations when this research is ongoing such as time lag effects, various financial ratios may be the possible indicators, and difficulty in retrieving annual report. This research is to investigate the performance of Domestic Malaysian banks before and after acquisition and two cases were chosen which are RHB Bank Berhad with Bank Utama (Malaysia) Berhad, and Hong Leong Bank Berhad with EON Bank Berhad. The performance after acquisition among the banks could have been different. Certain banks are able to achieve better performance in a short period, whereas, some banks may need a longer period of time to achieve it. There are many more financial ratios that can be used to examine the performance of a mergers and acquisition case other than the ones mentioned in this research. Therefore, there is no definite answer which ratios has the most appropriate outcome in measuring the performance of before and after acquisition between banks or firms. The answer may be indecisive when using different financial ratios, it may also give questionable evidence.

This research data are mostly from annual report from selected banks and historical prices which belong into the category of secondary data. However, certain historical price cannot be found in any reliable website such as KLSE website, Yahoo Finance, and Google Finance. Other than that, different website may have different historical prices on the same bank which may cause the result to vary and the answer may not give definite evidence. In addition, in order to be listed in KLSE, a bank or company must be listed in Bursa Malaysia first. Some banks that underwent acquisition were not listed in Bursa Malaysia, therefore, is difficult to retrieve the historical price and the annual report. 


\section{Conclusion}

In conclusion, there was not enough and solid evidence to prove that mergers and acquisition helps in performing better for Malaysian domestic banks. However, there was some improvement for Hong Leong Bank and EON Bank. RHB Bank on the other hand was outperforming by Bank Utama. This shows that the event announcement for RHB Bank and Bank Utama has not much affected compared to Hong Leong Bank and EON Bank. Overall, the result has no absolute significant relationship between the dependent variable and the independent variables especially for RHB bank as there were not much improvement in terms of financial ratio and abnormal return. This may be due to the debt RHB has before the announcement as it was higher than the debt to equity ratio of Bank Utama. Many reasons may cause a bank not to be able to perform well. It can be due to different era of economic or time as different banks need different time to improve and different economic environment may influence a banks' situation as well.

\section{References}

Brigham, E. F., \& Houston, J. F. (2007). Essential of Financial Management. Singapore: Cengage Learning Asia Pte Ltd.

Capron, L., \& Pistre, N. (2002). When do acquirers earn abnormal returns? Strategic Management Journal, 23(9), 781-794. https://doi.org/10.1002/smj.262

Graham, B., \& Zweig, J. (2003). The Intelligent Investor: The Definitive Book on Value Investing. A Book of Practical Counsel (Revised Edition). New York: Harper Collins Publisher.

Gyimah, S. F., \& Oscar, A. J., (2011). Effects of Share Pricing on Firms' Performance in Ghana. Journal of Economics and Sustainable Development, 2(4), 140-153.

Liargovas, P., \& Repousis, S. (2011). The impact of Mergers and Acquisitions on the Performance of the Greek Banking Sector: An event study approach. International Journal of Economics and Finance, 3(2), 89-100. https://doi.org/10.5539/ijef.v3n2p89

Ong, T. S., \& Ng, P. P. (2013). Capital structure before and after merger and acquisition: Banking industry in Malaysia. International Journal of Management Sciences and Business Research, 2(1), 1-22.

Said, R. M., Nor, F. M., Low, S. W., \& Rahman, A. A. (2008). The efficiency effect of mergers and acquisitions in Malaysian banking institutions. Asian Journal of Business and Accounting, 1(1), 47-66.

Shanmugam, B., \& Nair, M. (2003). Mergers and acquisition of banks in Malaysia. Managerial Finance, 30(4), 1-18. https://doi.org/10.1108/03074350410768994

Song, M. H. and Walkling, R. A., Abnormal Returns to Rivals of Acquisition Targets: A Test of the Acquisition Probability Hypothesis (2000). Journal of Financial Economics, 55(1), 143-171. https://doi.org/10.1016/S0304-405X(99)00048-3

Sufian, F., \& Abdul Majid, M. Z. (2005). Post-merger banks' efficiency and risk in emerging market: Evidence from Malaysia. Icfai University Journal of Bank Management, 4(4), 16-37.

Sufian, F., \& Habibullah, M. S. (2009). Do mergers and acquisitions lead to a higher technical and scale efficiency? A counter evidence from Malaysia. African Journal Business Management, 3(8), 340-349.

Talha, M., \& Sallehhuddin, A. (2005). Impact of merger and acquisition on debt management ratio: Acase study in Malaysian banking sectors. International Business \& Economics Research Journal, 4(11), 65-76.

Terjesen, S. (2009). Mergers and Acquisitions: Patterns, Motives, and Strategic Fit, Qfinance Best Practice. Retrieved from http://www.financepractitioner.com/contentFiles/QF02/glus0fc1/12/0/mergers-and-acquisitions-patterns-mot ives-and-strategic-fit.pdf

\section{Copyrights}

Copyright for this article is retained by the author(s), with first publication rights granted to the journal.

This is an open-access article distributed under the terms and conditions of the Creative Commons Attribution license (http://creativecommons.org/licenses/by/4.0/). 